Revista Brasil. Bot., V.30, n.4, p.703-711, out.-dez. 2007

\title{
Water relations of tree species growing on a rock outcrop in the "Parque Estadual de Itapuã", RS
}

\author{
LUIZ GUSTAVO RABAIOLI DA SILVA ${ }^{1}$ and LÚCIA REBELLO DILLENBURG ${ }^{1,2}$
}

(received: September 9, 2004; accepted: October 24, 2006)

\begin{abstract}
Water relations of tree species growing on a rock outcrop in the "Parque Estadual de Itapuã", RS). Water relations of the tree species Myrsine umbellata Mart. ex A. DC., Dodonaea viscosa Jacq. and Erythroxylum argentinum O. E. Schulz, growing on a rock outcrop in the "Parque Estadual de Itapuã" (RS), were studied. Environmental (precipitation, temperature, soil water) and plant (water potential, vapor pressure deficit, stomatal conductance, transpiration, leaf specific hydraulic conductance, osmotic potential and cell wall elasticity) parameters were collected in five periods and pooled into two sets of data: wet and dry periods. Myrsine umbellata showed great stability of the plant parameters, including the maintenance of high pre-dawn $\left(\Psi_{\text {wpd }}\right)$ and mid-day $\left(\Psi_{\text {wmd }}\right)$ water potentials in the dry period (-0.48 and $-1.12 \mathrm{MPa}$, respectively), suggesting the presence of a deep root system. Dodonaea viscosa and E. argentinum reached lower $\Psi_{\text {wpd }}(-1.41$ and $-1.97 \mathrm{MPa}$, respectively) and a greater degree of stomatal closure in the dry period, suggesting a shallower root system. Differential exposure to soil drought was also corroborated by differential drought effects on the whole-plant leaf specific hydraulic conductance $\left(G_{t}\right)$. Correlation analysis pointed to weak correlations between $\Psi_{\text {wpd }}$ and $g_{s}$. Erythroxylum argentinum was the only species to show osmotic adjustment in response to drought. It is suggested that $M$. umbellata has low tolerance to water deficits, adopting an avoidance behavior. The much lower values of $\Psi_{\mathrm{w}}$ reached by $D$. viscosa and $E$. argentinum suggest a greater tolerance to drought by these species.
\end{abstract}

Key words - Dodonaea viscosa, Erythroxylum argentinum, Myrsine umbellate, rock outcrops, water relations

RESUMO - (Relações hídricas de espécies arbóreas em um afloramento rochoso no Parque Estadual de Itapuã, RS). Foram examinadas neste estudo as relações hídricas das espécies Myrsine umbellata Mart. ex A. DC., Dodonaea viscosa Jacq. e Erythroxylum argentinum $\mathrm{O}$. E. Schulz, ocorrentes em um afloramento rochoso no Parque Estadual de Itapuã, RS. Parâmetros ambientais (precipitação, temperatura, água no solo) e das plantas (potencial hídrico, déficit de pressão de vapor, condutância estomática, transpiração, condutância hidráulica, potencial osmótico e elasticidade da parede celular) foram coletados em cinco períodos e agrupados em dois conjuntos de dados: períodos úmido e seco. Myrsine umbellata mostrou grande estabilidade dos parâmetros vegetais, incluindo a manutenção de altos potenciais hídricos de base $\left(\Psi_{\text {wpd }}\right)$ e de meio-dia ( $\left.\Psi_{\text {wmd }}\right)$, mesmo no período seco (-0,48 e -1,12 MPa, respectivamente), sugerindo a presença de um sistema radicular profundo. Dodonaea viscosa e E. argentinum apresentaram menores $\Psi_{\text {wpd }}(-1,41$ and -1,97 MPa, respectivamente) e maior fechamento estomático no período seco, sugerindo um sistema radicular mais superficial. Exposição diferenciada à seca do solo foi também corroborada pelos efeitos diferenciados da seca na condutância hidráulica folha-específica da planta. Análises de correlação indicaram fracas correlações entre $\Psi_{\text {wpd }}$ e $g_{s}$. Erythroxylum argentinum foi a única espécie a mostrar ajuste osmótico em resposta à seca. Sugere-se que $M$. umbellata seja pouco tolerante a déficits hídricos, adotando uma estratégia de evitação. Os menores $\Psi_{\mathrm{w}}$ alcançados por D. viscosa e E. argentinum sugerem maior tolerância destas espécies à seca.

Palavras-chave - afloramentos rochosos, Dodonaea viscosa, Erythroxylum argentinum, Myrsine umbellata, relações hídricas

\section{Introduction}

Rock outcrops (inselbergs) are places where bedrock is exposed at the surface (Skinner \& Porter 1992) and are widely distributed in tropical and subtropical regions (Porembski \& Barthlott 2000, Hunter 2003a). Rocks which are close to the surface tend to be brittle and, then, to be cut by innumerable fractures. This may significantly increase the usual low porosity of igneous rocks, such

\footnotetext{
1. Universidade Federal do Rio Grande do Sul, Departamento de Botânica, Avenida Bento Gonçalves 9500, 91501-970 Porto Alegre, RS, Brazil

2. Corresponding author: lucia.dillenburg@ufrgs.br
}

as granite. If these fractures are highly interconnected, a high-quality aquifer (a body of highly permeable rock or regolith lying in the zone of saturation, which yields significant quantities of water) may be present (Skinner \& Porter 1992, Thompson \& Turk 1993).

Vegetation in these outcrops differs considerably from the surrounding one, due to peculiar soil (thin layer) and microclimatic (high irradiance and evaporation) conditions (Porembski et al. 1998, 2000, Hunter 2003b), and it displays interesting patterns of distribution and substrate affinity (Meirelles et al. 1999). In these environments, plant species commonly arrange themselves to form elliptical soil-island plant communities, which vary in size from a few square centimeters to several 
hundreds square meters (Meirelles et al. 1999). The slow pace of intemperization processes and high declivity result in the lack of water and of an adequate substrate for root development and also in a high degree of surface heating, such that a herbaceous or shrubby vegetation might be the less successional stage in such environments (Shure \& Ragsdale 1977). The presence of aquifers and the access of deep-rooted species to this source of ground water may affect species composition and vegetation dynamics in rock outcrops.

The stomatal response to water stress is essential for a plant's success, because it results in the control of water vapor exit from the leaf. When stomatal regulation balances transpiration with the efficiency of water supply to the leaves, leaf desiccation is avoided. It is then intuitive that maximum stomatal aperture and conductance should be limited by the water supply to the leaves. Plant hydraulic conductance then becomes an important characteristic determining operational values of stomatal conductance (Hubbard et al. 2001, Meinzer 2002). Mechanisms that control water loss may also be expressed at the cellular level, like those related to osmotic adjustment and cell wall elasticity (Colombo \& Teng 1992), which will have important effects on turgor maintenance and water absorption (Cheung et al. 1975, Abrams 1988, Jensen \& Henson 1990).

Tropical rock-outcrop soil islands have not been explored in the same detail as those in temperate regions. Although important plant ecology studies have been conducted in the past few years in rock outcrops in Brazil (e.g., Mattos et al. 1997, Meirelles et al. 1999, Porembsky \& Barthlott 2000), they are basically inexistent for the state of Rio Grande do Sul. Ecophysiological studies in such environments are not only extremely interesting because of their peculiar conditions, but are also of major importance for the understanding of the vegetation dynamics and for the characterization of the morphological and physiological mechanisms that allow plant species to thrive in the somewhat extreme conditions of rock outcrops. This study aimed to evaluate the soil and atmosphere water conditions of a granitic outcrop in southern Brazil, under wet and dry conditions, to relate such conditions to the water use patterns of selected tree species, and to analyze and compare the contributions of stomatal aperture regulation and of osmotic and cell wall elasticity adjustments to the drought resistance of these species.

\section{Materials and methods}

Study site - This study was conducted in a rock outcrop of the "Parque Estadual de Itapuã", located in the town of Viamão,
Rio Grande do Sul, Brazil $\left(30^{\circ} 22^{\prime} \mathrm{S}\right.$ and $\left.51^{\circ} 02^{\prime} \mathrm{W}\right)$. This outcrop has a little pronounced westward inclination. The climate of the region is characterized by mean annual precipitation and temperature of about $1.200 \mathrm{~mm}$ and $17.5^{\circ} \mathrm{C}$, respectively, by the lack of a dry season and by high atmospheric humidity, which is associated to air masses of coastal origin and to the proximity of big lagoons (Universidade Federal do Rio Grande do Sul 1982). The litolic soils of the Park are of recent origin and classified as Litolic Neosoils (Streck et al. 2002). These are well-drained, dark-colored soils, derived from granitic rocks (Rio Grande do Sul 1997). Soil depth at the study site varied from about 10 to $30 \mathrm{~cm}$, and some of its chemical characteristics are presented in table 1.

Table 1. Chemical characteristics of the soil in the studied rock outcrop. Analyses were made in a compound sample made up of soil collected in five of the six vegetation islands selected in this study (two adjacent vegetation islands provided only one soil sample), from a depth between 0 and $30 \mathrm{~cm}$. Clay content determined by density analysis. $\mathrm{pH}$ measured in water solution $(1: 1 ; \mathrm{v}: \mathrm{v})$. Organic matter $(\mathrm{OM})$ obtained by multiplying the organic carbon (measured by humid digestion) content by 1.72 . Determination of $\mathrm{P}$ and $\mathrm{K}$ based on the Mehlich I method. Exchangeable $\mathrm{Ca}, \mathrm{Mg}$. $\mathrm{Al}$, and $\mathrm{Mn}$ extracted with $\mathrm{KCl} 1 \mathrm{~mol} \mathrm{~L}^{-1}$ Analyses were performed by the "Laboratório de Análises do Departamento de Solo da Universidade Federal do Rio Grande do Sul".

\begin{tabular}{lr}
\hline Soil parameter & Value \\
\hline Clay $(\%)$ & 19.0 \\
$\mathrm{pH}$ & 4.3 \\
$\mathrm{P}\left(\mathrm{mg} \mathrm{L}^{-1}\right)$ & 8.4 \\
$\mathrm{~K}\left(\mathrm{mg} \mathrm{L}^{-1}\right)$ & 97.0 \\
$\mathrm{OM}(\%)$ & 3.9 \\
$\mathrm{Al}\left(\mathrm{cmol}_{\mathrm{c}} \mathrm{L}^{-1}\right)$ & 2.8 \\
$\mathrm{Ca}\left(\mathrm{cmol}_{\mathrm{c}} \mathrm{L}^{-1}\right)$ & 0.7 \\
$\mathrm{Mg}\left(\mathrm{cmol}_{\mathrm{c}} \mathrm{L}^{-1}\right)$ & 0.6 \\
$\mathrm{Al}+{\mathrm{H}\left(\mathrm{cmol}_{\mathrm{c}} \mathrm{L}^{-1}\right)}_{\mathrm{Cation} \mathrm{Exchange} \mathrm{Capacity}\left(\mathrm{cmol}_{\mathrm{c}} \mathrm{L}^{-1}\right)}$ & 8.0 \\
Al saturation & 9.6 \\
Base saturation & 16.0 \\
\hline
\end{tabular}

Selected species - Myrsine umbellata Mart. ex A. DC. ("capororoca"), Dodonaea viscosa Jacq. ("vassoura-vermelha") and Erythroxylum argentinum O. E. Schulz ("cocão") were selected for this study. They are all evergreen species with wide distribution in the state of Rio Grande do Sul. Myrsine umbellata and E. argentinum are reported to grow in various types of soil, are characteristic of the initial stages of succession, can tolerate shade (Amaral 1980, Reitz et al. 1988, Ferrer 1999), but little is known about their drought tolerance. Dodonaea viscosa is a sun, drought-tolerant species that is particularly abundant in human-disturbed areas (Reitz 1980). In the "Parque Estadual de Itapuã", M. umbellata and $E$. 
argentinum have a very wide distribution, and they can appear as either shrubs or trees, depending on soil conditions. In the rock outcrops of the State Park, they usually co-habit the same vegetation islands, with heights that range from one to three meters. At the edges of these islands, and always under high irradiances, $D$. viscosa thrives, with heights that do not exceed three meters. Table 2 summarizes some growth and morphological characteristics of the selected species in the study site, and shows that $M$. umbellata has leaves which are much larger and have about twice the specific mass when compared to the other two.

Sampling design - Six individuals of each species were selected for measurements of the water relations parameters. Each one of these individuals was located on a different vegetation island. The vegetation islands were treated as blocks in the experimental design and each contained one of the six individuals of each species, totaling six vegetation islands (hereon treated as sampling points) and 18 individuals (experimental units). The size of the vegetation islands ranged from 7.85 to $500 \mathrm{~m}^{2}$, and the individuals sampled in this study were always located at the edges of the islands (E. argentinum and M. umbellata) or just outside them (D. viscosa). Data were collected in five different days: March 19, May 03, August 20, and October 11 of 2003, and January 03 of 2004. Measurements taken on these dates were grouped into two sets of days, according to the total precipitation along the 10 days that preceded them: wet period (data collected in March, May and October) and dry period (data collected in August and January). Mean values of maximum and minimum temperatures for the sampling dates plus the 10 preceding days were $25.2{ }^{\circ} \mathrm{C}$ and $18.2{ }^{\circ} \mathrm{C}$ for the wet period and $24.9^{\circ} \mathrm{C}$ and $13.3^{\circ} \mathrm{C}$ for the dry period. Total precipitation averaged $59.4 \mathrm{~mm}$ for the 10 preceding days in the wet period (34.8, 64.4 and $79.1 \mathrm{~mm}$ for the months of March, May and October, respectively), and was null for the dry period (figure 1). This data pooling procedure provided a better and cleaner picture of the effects of soil drought on the water relations of the species. A previous analyses of the data revealed that the drought of the atmosphere, as measured by the leaf-to-air vapor pressure deficit at mid-morning, did not differ significantly between the two dates associated to the dry period $(1.20 \mathrm{kPa}$ in August and $1.62 \mathrm{kPa}$ in January), but differed significantly between measurements taken in March $(2.11 \mathrm{kPa})$ and those taken in May $(0.70 \mathrm{kPa})$ and October $(1.00 \mathrm{kPa})$. Some implications of such difference within the wet period will be latter discussed.

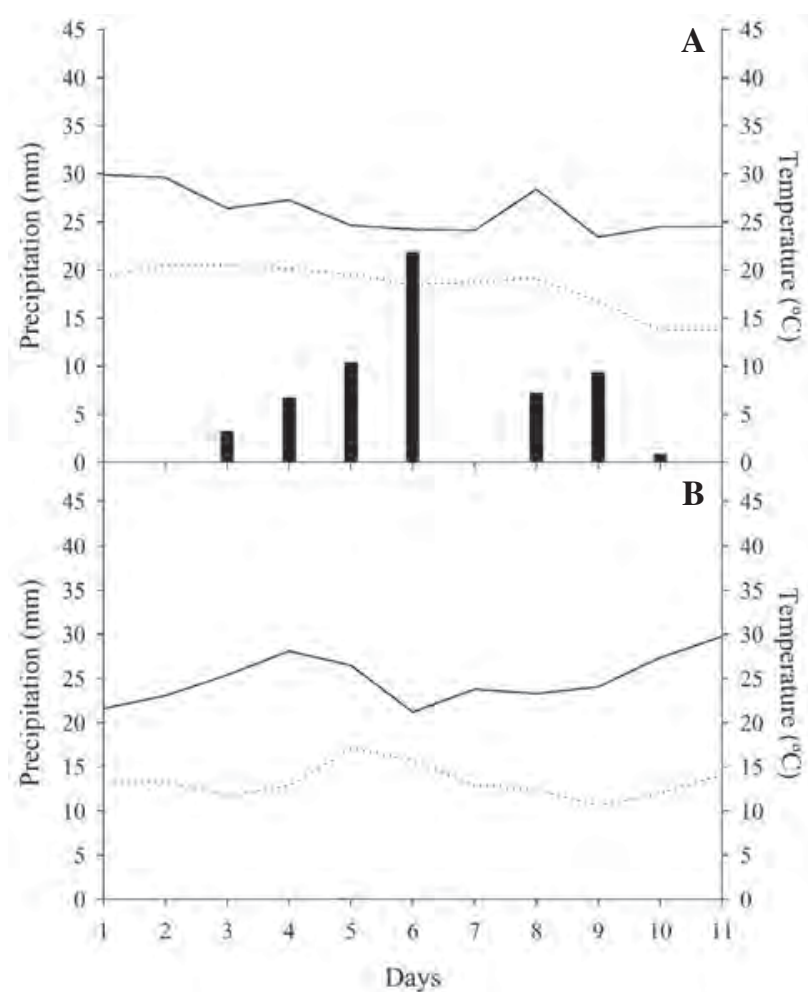

Figure 1. Precipitation and air temperature in the ten days preceding the sampling date (day 11). A. Wet period (values are averages of data related to sampling dates in March, May and October). B. Dry period (values are averages of data related to sampling dates in August and January). Precipitation (ם); Maximum temperature (...); Minimum temperature (-).

Shoot water potential $\left(\Psi_{\mathrm{w}}\right)-$ Due to the destructive nature of these measurements, only one shoot per individual was measured. Measurements were taken between 4 h 30 min and $6 \mathrm{~h}$ (predawn shoot water potential $-\Psi_{\text {wpd }}$ ) and between $12 \mathrm{~h}$ and $13 \mathrm{~h}$ (mid-day shoot water potential $-\Psi_{\text {wmd }}$ ). For both measurements, sun-exposed leafy shoots of similar size $(15-20 \mathrm{~cm})$ and position within the crown among individuals and species were sampled. A Scholander-type pressure chamber (Series 3000, Soil Moisture Equipment Corp, Santa Bárbara, CA) was used for water potential evaluations of the leafy shoots, and the values presented are averages of six individuals measured in three different days for the wet period $(n=18)$ and in two different days for the dry period $(n=12)$.

Leaf stomatal conductance $\left(\mathrm{g}_{\mathrm{s}}\right)$ and transpiration $(\mathrm{E})-$ For these measurements, three fully-expanded, sun-exposed

Table 2. Some growth characteristics of the selected tree species in the study site. Values of leaf size and leaf mass per area are means $( \pm \mathrm{SE})$ of compound leaf samples collected from each of the six individuals of each species sampled in this study.

\begin{tabular}{|c|c|c|c|c|}
\hline Species & Growth form & $\begin{array}{l}\text { Habitat light } \\
\text { conditions }\end{array}$ & $\begin{array}{c}\text { Size of mature } \\
\text { leaves }\left(\mathrm{cm}^{2}\right)\end{array}$ & $\begin{array}{l}\text { Leaf mass per } \\
\text { area }\left(\mathrm{g} \mathrm{m}^{-2}\right)\end{array}$ \\
\hline Myrsine umbellata & Small tree or shrub & Sun & $150.60 \pm 6.85$ & $211.29 \pm 7.89$ \\
\hline Dodonaea viscosa & Small tree & Sun & $24.23 \pm 1.74$ & $102.64 \pm 6.62$ \\
\hline Erythroxylum argentinum & Small tree & Sun & $31.86 \pm 2.43$ & $120.12 \pm 4.01$ \\
\hline
\end{tabular}


leaves per plant were sampled and treated as sub-samples of the experimental units. The abaxial surface of each leaf (there was no measurable conductance in the adaxial surface) was measured with a steady-state porometer (Li-1600, Li-Cor, Inc., Lincoln, NE) at two different times during the day: between $9 \mathrm{~h}$ and $10 \mathrm{~h} 30 \mathrm{~min}$ (morning stomatal conductance $-\mathrm{g}_{\text {smor }}-$ and transpiration $-\mathrm{E}_{\mathrm{mor}}$ ) and between $14 \mathrm{~h}$ and $15 \mathrm{~h}$ 30 min (afternoon stomatal conductance $-\mathrm{g}_{\text {saft }}-$ and transpiration $-\mathrm{E}_{\mathrm{aft}}-$ ). The values $\mathrm{g}_{\mathrm{s}}$ and $\mathrm{E}$ reported in this study are averages of six individuals measured in three different days for the wet period $(n=18)$ and in two different days for the dry period $(n=12)$.

Whole-plant leaf specific hydraulic conductance $\left(G_{t}\right)-$ It was estimated as the ratio between $\mathrm{E}_{\text {aft }}$ and the drop of $\Psi_{\mathrm{w}}$ from pre-dawn to mid-day ( $\Psi_{\text {wpd }}-\Psi_{\text {wmd }}$ ).

Microclimate conditions - At each time a leaf was sampled for $g_{s}$ and $E$, leaf temperature $\left(T_{1}\right)$ was also recorded by a leaf thermocouple located inside the porometer chamber. Temperature and relative humidity of the air around the islands was recorded every thirty minutes along each day of measurement with and electronic data-logger equipment (LogBox, Novus). Based on these air temperature and humidity data and on $\mathrm{T}_{1}$, the leaf-to-air vapor pressure deficit (VPD) was calculated for the two times of the day when $\mathrm{g}_{\mathrm{s}}$ and $\mathrm{E}$ were measured (morning $-\mathrm{VPD}_{\text {mor }}-$ and afternoon $-\mathrm{VPD}_{\text {aft }}$ ). Pressure-volume curves - These curves were constructed based on three shoots of each species (each shoot collected from one individual growing in three previously selected islands), which were always collected from sun-exposed regions of the crown and had similar positions among individuals and species. Shoots were cut in the field between $8 \mathrm{~h}$ and $9 \mathrm{~h}$ on the same sampling dates already reported, had their the cut stems immediately placed under distilled water, and were covered wit black plastic to prevent transpirational water loss. Back in the lab, they were recut under water (Parker et al. 1982), and let to rehydrate under darkness for $20 \mathrm{~h}$. Each shoot was then weighed (turgid weight) and immediately placed inside the pressure chamber. The pressure inside the chamber was slowly increased until the water potential of the turgid shoot could be recorded. Pressure was then slowly released (-0.02 $\left.\mathrm{MPa} \mathrm{s}^{-1}\right)$ to avoid damage to the plant tissues. The shoot was then released from the chamber and placed on a bench top for natural drying (free-transpiration method, Parker \& Pallardy 1988). Successive measurements of fresh weight and water potential of the shoot were made until there was only about $40 \%$ of the water present in the turgid state. The plant material was then oven-dried $\left(80{ }^{\circ} \mathrm{C}\right)$ and weighed. The relative water content (RWC) associated to each measurement of water potential was calculated as (Fresh weight - Dry weight) / (Turgid weight - Dry weight] x 100. From the mathematical relationship between RWC and the inverse of water potential (Sigmaplot 5.0, SPSS, Science), estimates were made of the osmotic potentials at full turgor $\left(\Psi \pi_{(100)}\right)$ and zero turgor $\left(\Psi \pi_{(0)}\right)$, and of the bulk modulus of elasticity $(\varepsilon)$ (Tyree \& Hammel 1972, Ritchie \& Hinckley 1975, Jensen \& Henson
1990) The region of the curve between full and zero turgor was used on the estimation of $\varepsilon$. Values reported for the different parameters extracted from these curves are averages of three individuals measured in three different days for the wet period $(n=9)$ and in two different days for the dry period $(n=6)$.

Soil water content (SWC) - A compound soil sample made up of five sub-samples collected with an auger, between 0 and $30 \mathrm{~cm}$ of soil depth, in each vegetation island (two adjacent vegetation islands provided only one soil sample) was weighed, air-dried, and then reweighed for estimation of the gravimetric soil water content [(fresh weight-dry weight) / dry weight $* 100]$. The values reported are averages for the wet $(n=15)$ and dry $(n=10)$ periods.

Statistical analysis - Mean values of shoot water potential, stomatal conductance and transpiration for each period (wet and dry) and species were statistically compared using an aleatorization test, based on the Euclidean distance between experimental units, and taking into account block, period and species as sources of variation. For statistical analysis of SWC, sources of variation included only block and period. These analyses were made with the aid of the statistical program Multiv minor 2.1.1 (Pillar 2003). Correlation analyses between parameters were made using Sigmaplot 5.0 (SPSS Inc.).

\section{Results}

Soil water content was about $58 \%$ greater in the wet than in the dry period (figure 2A). Differences in SWC resulted in $\Psi_{\text {wpd }}$ and $\Psi_{\text {wmd }}$ values which were also greater in the wet than in the dry period (figure $2 \mathrm{~B}, \mathrm{C}$ ). An important exception was the $\Psi_{\text {wmd }}$ of $M$. umbellata, which did not vary significantly between the two periods. In the wet period, $\Psi_{\text {wpd }}$ was greater in $M$. umbellata than in D. viscosa and the $\Psi_{\text {wmd }}$ was greater in $M$. umbellata than in both D. viscosa and E. argentinum. In the dry period, both $\Psi_{\text {wpd }}$ and $\Psi_{\text {wmd }}$ of $M$. umbellata were greater than the corresponding values of $D$. viscosa and E. argentinum.

Significant differences in leaf-to-air VPD between the wet and dry periods were present only for measurements taken in the afternoon, with the wet period showing the smaller values for all three species (figure $3 \mathrm{~A}, \mathrm{~B})$. There were no differences among species. The mean values of $g_{\text {smor }}$ and $g_{\text {saft }}$ were greater in the wet than in the dry periods Differences among species were only present in the dry period, when $M$. umbellata showed greater values of both $\mathrm{g}_{\text {smor }}$ and $\mathrm{g}_{\text {saft }}$ than $D$. viscosa and E. argentinum (figure $3 \mathrm{C}, \mathrm{D}$ ). Variations in $\mathrm{E}$ were mostly similar to those of $g_{s}$ : $E_{\text {mor }}$ and $E_{\text {aft }}$ were greater in the wet than in the dry period for both $D$. viscosa and $E$. argentinum. Contrary to $\mathrm{g}_{\mathrm{s}}, \mathrm{E}_{\mathrm{mor}}$ and $\mathrm{E}_{\mathrm{aft}}$ of $M$. umbellata did not vary between the two periods, and reached quite 
high values, especially in the afternoon (figure $3 \mathrm{E}, \mathrm{F}$ ). In the dry period, $\mathrm{E}_{\mathrm{mor}}$ and $\mathrm{E}_{\mathrm{aft}}$ of $M$. umbellata were greater than in the other two species. All species has similar values of $\mathrm{G}_{\mathrm{t}}$ in the wet period, and drought led to a significant reduction in $\mathrm{G}_{\mathrm{t}}$, except in M. umbellata, which then exhibited significantly higher values than the other two species (table 3).
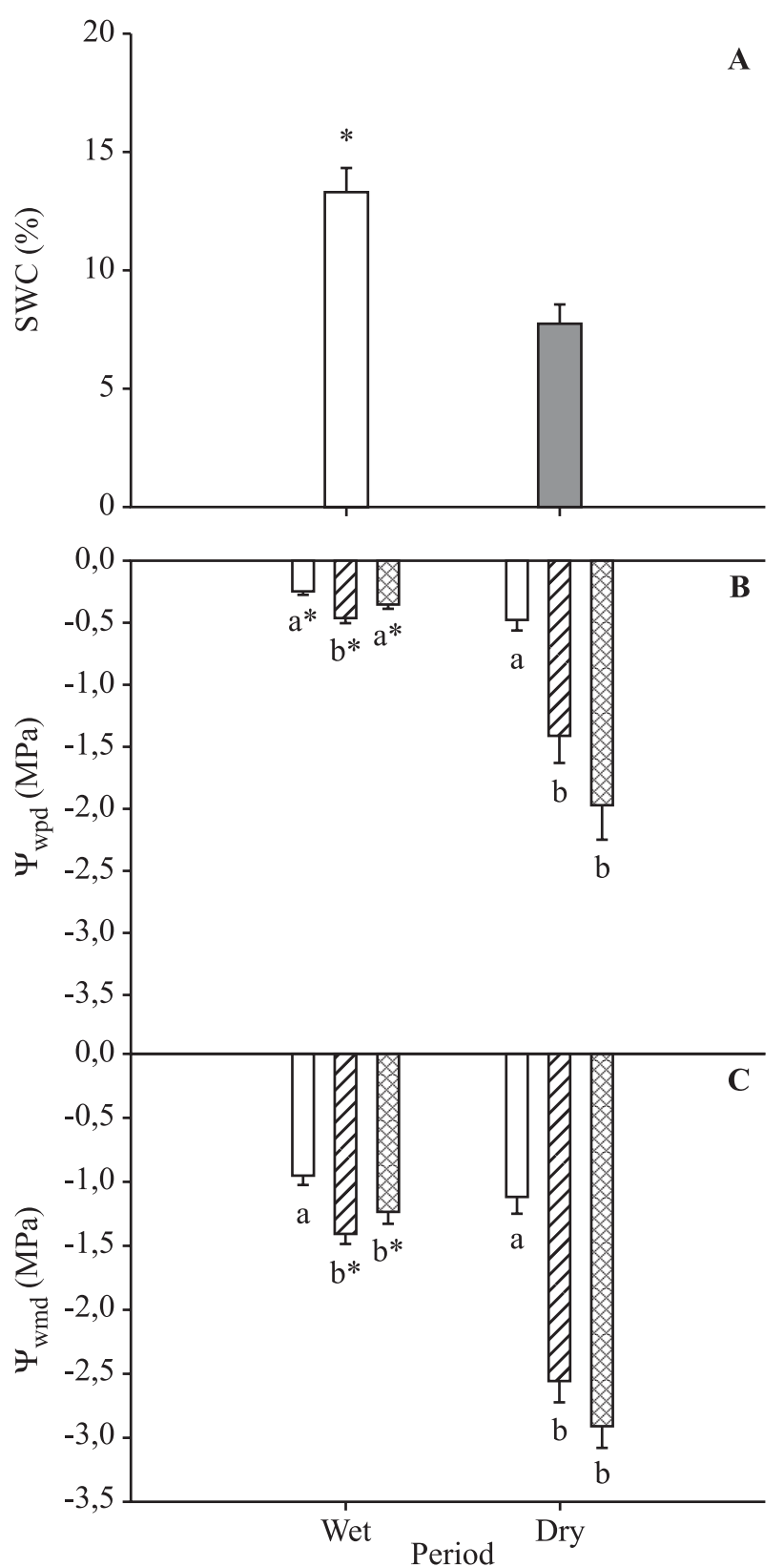

Figure 2. Measurements of soil and plant water availability in the wet and dry periods. A. Soil water content (SWC). B. Pre-dawn shoot water potential $\left(\Psi_{\text {wpd }}\right)$. C. Mid-day shoot water potential $\left(\Psi_{\text {wmd }}\right)$. Vertical bars indicate the standard error of the means, and an asterisk and different small letters indicate significant mean differences between periods and species, respectively $(P \leq 0.05)$. ( $\square=$ Myrsine umbellata; $\square=$ Dodonaea viscosa; 图 = Erythroxylum argentinum).
Table 3. Whole-plant leaf specific hydraulic conductance $\left(\mathrm{mmol} \mathrm{m} \mathrm{s}^{-2} \mathrm{~s}^{-1} \mathrm{MPa}^{-1}\right)$ Values are means \pm SE. Different capital and small letters indicate significant mean differences between periods and species, respectively $(\mathrm{P} \leq 0.05)$.

\begin{tabular}{lccc}
\hline Period & $\begin{array}{c}\text { Myrsine } \\
\text { umbellata }\end{array}$ & $\begin{array}{c}\text { Dodonaea } \\
\text { viscosa }\end{array}$ & $\begin{array}{c}\text { Erythroxylum } \\
\text { argentinum }\end{array}$ \\
\hline Wet & $5.55 \pm 1.04 \mathrm{Aa}$ & $3.41 \pm 0.32 \mathrm{Aa}$ & $4.95 \pm 1.42 \mathrm{Aa}$ \\
Dry & $4.16 \pm 0.87 \mathrm{Aa}$ & $1.26 \pm 0.25 \mathrm{Bb}$ & $1.57 \pm 0.35 \mathrm{Bb}$ \\
\hline
\end{tabular}

Daily variations in leaf-to-air and air-to-air VPD were poorly correlated to variations in $\mathrm{E}$ and $\mathrm{g}_{\mathrm{s}}$ for all three species $\left(r^{2} \leq 0.14\right)$. Values of $\Psi_{\mathrm{b}}$ also showed a weak linear correlation with $\mathrm{g}_{\text {smor }}\left(r^{2} \leq 0.14\right)$, but a bit higher with $\mathrm{g}_{\text {saft }}$. In this last case, the coefficient of determination was much lower for E. argentinum $\left(r^{2}=0.03\right)$ than for M. umbellata $\left(r^{2}=0.32\right)$ and D. viscosa $\left(r^{2}=0.38\right)$.

Both estimates of shoot osmotic potential, $\Psi_{\pi(100)}$ and $\Psi_{\pi(0)}$, reduced in the dry compared with the wet period only for Erythroxylum argentinum. The species differ from each other only in the wet period, with $M$. umbellata showing more negative values of both $\Psi_{\pi(100)}$ and $\Psi_{\pi(0)}$ than D. viscosa and E. argentinum. The cell wall elasticity parameter, e, did not vary between the wet and dry period but was significantly greater in $M$. umbellata than in D. viscosa and E. argentinum in the wet period (table 4).

\section{Discussion}

Estimating rooting depth from values of $\Psi_{\text {wpd }}$ Measurements of $\Psi_{\text {wpd }}$ have commonly been used as estimates of soil $\Psi_{w}$, based on the assumption that, during the night, the plant $\Psi_{\mathrm{w}}$ reaches an equilibrium with the $\Psi_{\mathrm{w}}$ of the soil explored by the absorbing roots (Reich \& Hinckey 1989, Boyer 1995, Donovan et al. 2003). When comparing individuals that co-habit a particular space, those that reach the greatest values of $\Psi_{\text {wpd }}$ most likely have a greater access to soil water, commonly indicating a greater rooting depth. The distinction of $\Psi_{\text {wpd }}$ among individuals with different rooting depths becomes more evident as the soil profile dries. Thus, during the wet period, values of $\Psi_{\text {wpd }}$ were similarly high in all species. However, in the dry period, when soil water between 0 and $30 \mathrm{~cm}$ depth fell to about half the values measured in the wet period, both $D$. viscosa Jacq. and E. argentinum O. E. Schulz exhibited major reductions in $\Psi_{\text {wpd }}$, while that of M. umbellata Mart. ex A. DC was little affected. It is then suggested that $D$. viscosa and E. argentinum have a greater dependence on the water present in the 

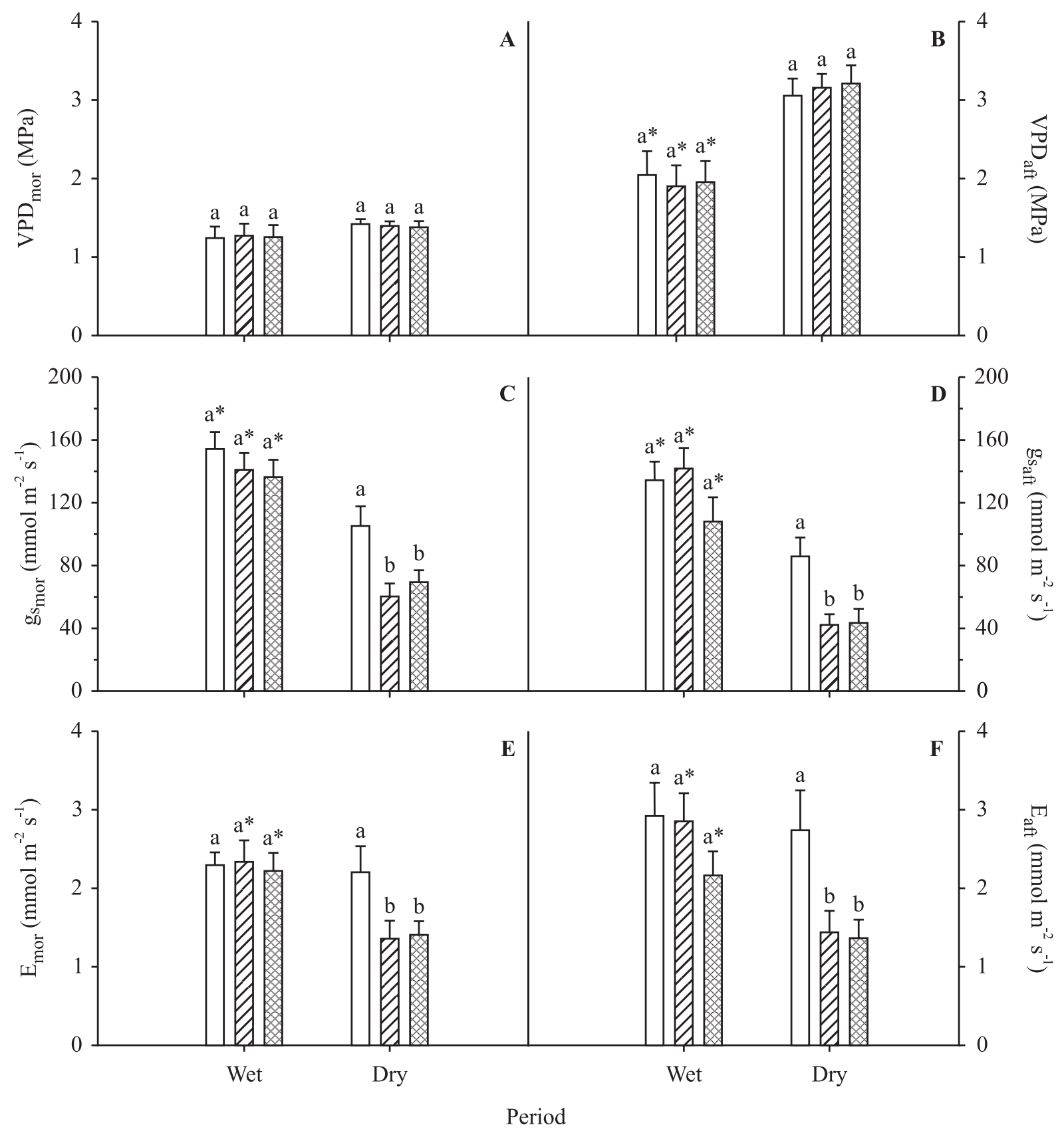

Figure 3. Measurements related to leaf water loss in the wet and dry periods, for both morning (mor) and afternoon (aft) hours. A, B. Leaf-to-air vapor pressure deficit (VPD). C, D. Leaf stomatal conductance $\left(\mathrm{g}_{\mathrm{s}}\right)$. E, F. leaf transpiration (E). Vertical bars indicate the standard error of the means, and an asterisk and different small letters indicate significant mean differences between periods and species, respectively $(P \leq 0.05)$. $(\square=$ Myrsine umbellata; $\square=$ Dodonaea viscosa; : $=$ Erythroxylum argentinum).

upper layers of the soil than does M. umbellata, indicating a greater rooting depth of this species, compared to the others. Despite the thin layer of soil in the outcrop, access to ground water reservoirs could take place by root growth through rock fractures. However, any conclusion regarding the depth of roots based on pre-dawn values of shoot water potential must be made with some caution, because of the possible occurrence of pre-dawn disequilibrium, to which several mechanisms may contribute: loss of contact between roots and soil in dry areas, nocturnal transpiration, apoplastic solute concentration in leaf intercellular spaces, and hydraulic lift (Donovan et al. 2001, 2003).

In contrast to the other two species, leaf transpiration of $M$. umbellata was remarkably unaffected by soil drought. However, the species did exhibit a significant reduction in stomatal conductance in response to drought, but to 
Table 4. Water relations parameters derived from the pressure-volume curves $\left(\Psi \pi_{(100)}=\right.$ osmotic potential at full turgor, $\Psi \pi_{(0)}$ $=$ osmotic potential at zero turgor, $\varepsilon=$ bulk modulus of cell wall elasticity). Values are means \pm SE. Different capital and small letters indicate significant mean differences between periods and species, respectively $(P \leq 0.05)$.

\begin{tabular}{lcccc}
\hline Period & $\begin{array}{c}\text { Parameter } \\
(\mathrm{MPa})\end{array}$ & $\begin{array}{c}\text { Myrsine } \\
\text { umbellata }\end{array}$ & $\begin{array}{c}\text { Dodonaea } \\
\text { viscosa }\end{array}$ & $\begin{array}{c}\text { Erythroxylum } \\
\text { argentinum }\end{array}$ \\
\hline Wet & $\Psi \pi_{(100)}$ & $-1.89 \pm 0.05 \mathrm{Aa}$ & $-1.51 \pm 0.06 \mathrm{Ab}$ & $-1.40 \pm 0.08 \mathrm{Ab}$ \\
& $\Psi \pi_{(0)}$ & $-2.00 \pm 0.08 \mathrm{Aa}$ & $-1.77 \pm 0.07 \mathrm{Ab}$ & $-1.70 \pm 0.13 \mathrm{Ab}$ \\
& $\varepsilon$ & $19.83 \pm 2.19 \mathrm{Aa}$ & $10.77 \pm 0.60 \mathrm{Ab}$ & $13.57 \pm 1.61 \mathrm{Ab}$ \\
\hline Dry & $\Psi \pi_{(100)}$ & $-1.74 \pm 0.07 \mathrm{Aa}$ & $-1.37 \pm 0.22 \mathrm{Aa}$ & $-1.85 \pm 0.23 \mathrm{Ba}$ \\
& $\Psi \pi_{(0)}$ & $-1.89 \pm 0.10 \mathrm{Aa}$ & $-1.69 \pm 0.26 \mathrm{Aa}$ & $-2.33 \pm 0.26 \mathrm{Ba}$ \\
& $\varepsilon$ & $17.77 \pm 1.90 \mathrm{Aa}$ & $11.35 \pm 3.00 \mathrm{Aa}$ & $15.98 \pm 2.80 \mathrm{Aa}$ \\
\hline
\end{tabular}

a smaller extent than the other species, such that, under dry conditions, the species maintained higher stomatal conductance and transpiration rates than the others. These results, combined to the little variation in midday leaf water potential from the wet to the dry period, suggest a more adequate water supply to the leaves of M. umbellata under drought. This better supply could be provided by a greater root access to soil water, as attested by the much higher values of pre-dawn leaf water potential. Data on daily and seasonal variations of water relations of $M$. umbellata growing in the Brazilian "cerrado" showed that variations in soil water availability between the wet and dry seasons were not very pronounced and did not lead to stomatal closure, unless the VPD of the dry season was higher than that of the wet season (Mattos 1998). The little seasonal effect on the water potential of several woody species of the Brazilian "cerrado" has been explained by their deep rooting habit (Meinzer et al. 1999). The potential of $M$. umbellata for exploring deep soil layers may also be expressed in other environments, including underground water of rock outcrops.

Estimates of plant hydraulic conductance revealed that drought had a negative effect on the ability of $D$. viscosa and E. argentinum to conduct water to their leaves. Whole-plant leaf specific hydraulic conductance of $M$. umbellata, on the other hand, remained unaffected, which is consistent with the small variations in leaf water potential and transpiration between the wet and dry periods. Within-species, drought-related reductions in whole-plant hydraulic conductance may arise from different causes, including cavitations events and reductions in the exchange of water between storage components and transpiration stream (Meinzer 2002). The relative contributions of these factors to the observed reductions in hydraulic conductance in two of the three species cannot be determined.
Osmotic adjustment and cell wall elasticity - Shoot osmotic adjustment in response to soil drought was detected only in E. argentinum. The more limited access to soil water of $E$. argentinum (indicated by the lowest value of $\Psi_{\text {wpd }}$ in the dry period) probably resulted in the need for such osmotic adjustment. It is interesting to note that, during the wet period, the calculated value of $\Psi_{\pi}$ for M. umbellata was lower than those of the other two species. A low constitutive value of $\Psi_{\pi}$ may guarantee water absorption in situations where rooting depth does not ensure root access to more stable soil water conditions and may be of particular advantage for species that are commonly exposed to soil drought or which have low tolerance to water deficits. Cell wall elasticity did not vary from the wet to the dry period in any of the species, but $M$. umbellata had greater values of $\varepsilon$ than the other two species, particularly in the wet period, indicating an inherent low elasticity of shoot cell walls. Tissues with low cell wall elasticity can develop more negative water potentials and thus generate larger gradients for water uptake for a given volume of water loss (Abrams et al. 1990, Kloeppel et al. 1994). According to Nardini \& Salleo (2000), the ability to generate large gradients in $\Psi_{\mathrm{w}}$ allows plants to maximize gas exchange, enhancing carbon gain and productivity.

Drought avoidance $v s$ drought-tolerance - Based on the pronounced stability of the different water relation parameters displayed by $M$. umbellata, it can be concluded that this species deals with drought by mostly avoiding it. This is probably partly accomplished by a deep root system, which results in a more stable water supply. Its tolerance to desiccation is probably small and its success in drought-prone environments might depend on the access of its roots to soil regions that have a permanently adequate water supply. High constitutive levels of solute concentration in the cells and a constitutively low elasticity of the cell walls are 
probably important in establishing favorable gradients for water uptake during occasional situations of plant exposure to soil drought. Leaf temperature control is highly dependent on transpirational and convective heat exchange. This last type of exchange, by its turn, faces the resistance of the air boundary layer. Thus, the big leaf area of $M$. umbellata (at least five times greater than the other species) does not favor this mechanism of heat exchange, resulting in a greater dependence on transpiration in order to avoid damaging heat loads on its leaves. Its success in habitats that are prone to high irradiances and high air temperatures will probably depend on a continuous access to soil regions with adequate water availability, allowing the plant to maintain leaf temperature regulation through transpiration.

No osmotic adjustment was detected for D. viscosa under the experimental conditions, and this species showed pronounced reductions of $g_{s}$ in response to soil drought and large variations in $\Psi_{\mathrm{w}}$. Pronounced reductions in stomatal conductance during a dry period were also reported for $D$. viscosa individuals growing on a lava substratum (Barradas et al. 2004). Erythroxylum argentinum, by its turn, did show osmotic adjustment in response to soil drought. Both species attained greater fluctuations and more negative values of water potentials when compared to M. umbellata and expressed compensatory responses to the effects of low soil water availability (stomatal closure and/or osmotic adjustment), indicating a greater capacity to tolerate drought (Parker et al. 1982, Hinckley et al. 1983, Davis \& Mooney 1986).

Final remarks - A better characterization of the degree of drought tolerance of the three species will only be achieved when comparing their responses to equivalent reductions in soil water availability, which cannot be easily done under natural conditions, especially because of the strong indications of a greater rooting depth of $M$. umbellata. The results of this study provided important insights about the mechanisms of coexistence of the species. Myrsine umbellata and E. argentinum grow in close proximity in the vegetation islands, and their coexistence may be at least partly promoted by differential rooting depth. Dodonaea viscosa, on the other hand, does not tend compete below- or aboveground with the other species, because of the spatial separation of its individuals. Future studies focusing on the spatial and temporal partitioning of the water resource in these vegetation islands would certainly provide a better understanding of competition and facilitation processes among the involved species and of the vegetation dynamics on rock outcrops.
Acknowledgments - we are thankful to Fábio R. Scarano, Luís Mauro G. Rosa and João Ito Bergonci for valuable suggestions to earlier versions of this manuscript. We also thank the staff of the "Parque Estadual de Itapuã" for technical support, the Post-Graduate Program in Ecology of the "Universidade Federal do Rio Grande do Sul" for academic and financial support and "Capes/Brasil" ("Coordenação de Aperfeiçoamento de Pessoal de Nível Superior") for the master fellowship awarded to the first author.

\section{References}

ABRAMS, M.D. 1988. Sources of variation in osmotic potentials with special reference to North American tree species. Forest Science 34:1030-1046.

ABRAMS, M.D., SCHULTZ, J.C. \& KLEINER, K.W. 1990. Ecophysiological responses in mesic versus xeric hardwood species to an early-season drought in Central Pennsylvania. Forest Science 36:970-981.

AMARAL JÚNIOR, A. 1980. Eritroxiláceas. In Flora ilustrada catarinense (R. Reitz, ed.). Herbário Barbosa Rodrigues, Itajaí.

BARRADAS, V.L., RAMON-VÁSQUEZ, A. \& OROZCOSEGOVIA, A. 2004. Stomatal conductance in a tropical xerophilous shrubland at a lava substratum. International Journal of Biometeorology 48:119-127.

BOYER, J.S. 1995. Measuring the water status of plant and soil. Academic Press, San Diego.

CHEUNG, Y.N.S., TYREE, M.T. \& DAINTY, J. 1975. Water relations parameters on single leaves obtained in a pressure bomb and some ecological interpretations. Canadian Journal of Botany 53:1342-1346.

COLOMBO, S.J. \& TENG, Y. 1992. Seasonal variation in the tissue water relations of Picea glauca. Oecologia 92:410-415.

DAVIS, S.D. \& MOONEY, H.A. 1986. Tissue water relations of co-ocurring chaparral shrubs. Oecologia 70:527-535.

DONOVAN, L.A., LINTON, M.J. \& RICHARDS, J.H. 2001. Predawn plant water potential does not necessarily equilibrate with soil water potential under well-watered conditions. Oecologia 129:328-335.

DONOVAN, L.A., RICHARDS, J.H. \& LINTON, M. 2003. Magnitude and mechanisms of disequilibrium between predawn plant and soil water potentials. Ecology 84: 463-470.

FERRER, R.S. 1999. Respostas fisiológicas à disponibilidade de água e luz durante o crescimento inicial de plântulas de Myrsine umbellata (Martius ex De Candolle) Mez e Scutia buxifolia Reissek. Dissertação de mestrado, Universidade Federal do Rio Grande do Sul, Porto Alegre.

HINCKLEY, T.M., DUHME, F., HINCKLEY, A.R. \& RICHTER, H. 1983. Drought relations of shrub species - assessment of the mechanisms of drought resistance. Oecologia 59:344-350. 
HUBBARD, R.M., RYAN, M.G., STILLER, V. \& SPERRY, J.S. 2001. Stomatal conductance and photosynthesis vary linearly with plant hydraulic conductance in ponderosa pine. Plant, Cell and Environment 24:113-121.

HUNTER, J.T. 2003a. Factors affecting range size differences for plant species on rock outcrops in eastern Australia. Diversity and Distributions 9:221-220.

HUNTER, J.T. 2003b. Persistence on inselbergs: the role of obligate seeders and resprouters. Journal of Biogeography 30:497-510.

JENSEN, C.R. \& HENSON, I.E. 1990. Leaf water relations characteristics of Lupinus angustifolius and Lupinus cosentinii. Oecologia 82:114-121.

KLOEPPEL, B.D., KUBISKE, M.E. \& ABRAMS, M.D. 1994. Seasonal tissue water relations of four successional Pennsylvania barrens species in open and understory environments. International. Journal of Plant Science 155:73-79.

MATTOS, E.A. 1998. Perspectives in comparative ecophysiology of some Brazilian vegetation types: leaf $\mathrm{CO}_{2}$ and $\mathrm{H}_{2} \mathrm{O}$ gas exchange, chlorophyll $a$ fluorescence and carbon isotope discrimination. In Ecophysiological strategies of xerophytic and amphibious plants in the neotropics (F.R. Scarano \& A.C. Franco, eds.). Oecologia Brasiliensis, Universidade Federal do Rio de Janeiro, Rio de Janeiro, v.4, p.1-11.

MATTOS, E.A., GRAMS, T.E., BALL, E., FRANCO, A.C., HAAGKERWER, A., HERZOG, B., SCARANO, F.R., BARRETO, S.M.B. \& LÜTTGE, U. 1997. Diurnal patterns of chlorophyll a fluorescence and stomatal conductance in several species of coastal vegetation in southeastern Brazil. Trees 11:363-369.

MEINZER, F.C. 2002. Co-ordination of vapour and liquid phase water transport properties in plants. Plant, Cell and Environment 25: 265-274.

MEINZER, F.C., GOLDSTEIN, G., FRANCO, A.C., BUSTAMANTE, M., IGLER, E., JACKSON, P., CALDAS, L. \& RUNDEL, P.W. 1999. Atmospheric and hydraulic limitations on transpiration in Brazilian cerrado woody species. Functional Ecology 13:273-282.

MEIRELLES, S.T., PIVELLO, V.R. \& JOLY, C.A. 1999. The vegetation of granite rock outcrops in Rio de Janeiro, Brazil, and the need for its protection. Environmental Conservation 26:10-20.

NARDINI, A. \& SALLEO, S. 2000. Limitation of stomatal conductance by hydraulic traits: sensing or preventing xylem cavitation? Trees 15:14-24.

PARKER, W.C. \& PALLARDY, S.G. 1988. Pressure-volume analysis of leaves of Robinia pseudoacacia L. with the sap expression and free transpiration methods. Canadian Journal of Forest Research 18:1211-1213.
PARKER, W.C., PALLARDY, S.G., HINCKLEY, T.M. \& TESKEY, R.O. 1982. Seasonal changes in tissue water relations of three woody species of the Quercus-Carya forest type. Ecology 63:1259-1267.

PILLAR, V.D. 2003. Multiv, software para análise multivariada, testes de hipóteses e auto-reamostragem. Universidade Federal do Rio Grande do Sul, Porto Alegre.

POREMBSKI, S. \& BARTHLOTT, W. 2000. Granitic and gneissic outcrops (inselbergs) as centers of diversity for desiccation-tolerant vascular plants. Plant Ecology 151:19-28.

POREMBSKI, S., MARTINELLI, G., OHLEMÜLLER, R. \& BARTHLOTT, W. 1998. Diversity and ecology of saxicolous vegetation mats on inselbergs in the Brazilian Atlantic rainforest. Diversity and Distributions 4:107119.

REICH, P.B. \& HINCKLEY, T.M. 1989. Influence of pre-dawn water potential and soil-to-leaf hydraulic conductance on maximum daily leaf diffusive conductance in two oak species. Functional Ecology 3:719-726.

REITZ, R. 1980. Sapindáceas. In Flora ilustrada catarinense (R. Reitz, ed.). Herbário Barbosa Rodrigues, Itajaí.

REITZ, R., KLEIN, R.M. \& REIS, A. 1988. Projeto madeira do Rio Grande do Sul. Herbário Barbosa Rodrigues, Itajaí.

RIO GRANDE DO SUL. 1997. Plano de manejo do Parque Estadual de Itapuã-RS. Departamento de Recursos Naturais Renováveis, Porto Alegre.

RITCHIE, G.A. \& HINCKLEY, T.M. 1975. The pressure chamber as an instrument for ecological research. Advances in Ecological Research 9:165-254.

SHURE, D.J. \& RAGSDALE, H.L. 1977. Patterns of primary sucession on granite outcrop surfaces. Ecology 58:9931006.

SKINNER, B.J. \& PORTER, S.C. 1992. The dynamic earth. $2^{\text {nd }}$ ed. Wiley \& Sons, New York.

STRECK, E.V., KÄMPF, N., DALMOLIN, R.S.D., KLAMT, E., NASCIMENTO, P.C. \& SCHNEIDER, P. 2002. Solos do Rio Grande do Sul. Universidade Federal do Rio Grande do Sul, Porto Alegre.

THOMPSON, G.R. \& TURK, J. 1993. Modern physical geology. Saunders, Philadelphia.

TYREE, M.T. \& HAMMEL, H.T. 1972. The measurement of turgor pressure and the water relations of plants by the pressure-bomb technique. Journal of Experimental Botany 23:267-282.

UNIVERSIDADE FEDERAL DO RIO GRANDE DO SUL. 1982. Itapuã, análise preliminar do espaço geográfico. Universidade Federal do Rio Grande do Sul, Porto Alegre. 